\title{
PREFACE TO THE SPECIAL ISSUE ON THE 250TH ANNIVERSARY OF RUTGERS UNIVERSITY PART ONE: THE LIFE AND TIMES OF HENRY RUTGERS
}

\author{
BY ROBERT G. SEWELL \\ rgsewell@rulmail.rutgers.edu
}

In 2016, we are celebrating the 250th anniversary of Rutgers University. On November 10, 1766, the founding charter of Queen's College - which became Rutgers University—was granted by New Jersey's Governor, William Franklin. While that document is no longer extant as far as we know, there is historical evidence to confirm its existence. A second, modified charter was approved in 1770 , and a printed version of that charter is owned by Rutgers. The first class of Queen's College opened in 1771. In the article "Rutgers' 1870 Centennial Celebration and Other Charter-Related Puzzles," Caryn Radick reveals how the Rutgers centennial was celebrated in 1870 (the 100th anniversary of the second charter) and how the existence of the 1766 charter was discovered in the late nineteenth century. She also examines the origins and instances of the celebrations of Charter Day (November 10), which marks the anniversary of the first charter, and details how Rutgers came to acquire an early copy of the second charter. The article considers how it took a while for Rutgers to find the most positive narrative of its origin based on historical facts. This complicated tale is just a part of the unusual history of Rutgers.

Queen's/Rutgers is the eighth colonial college and is only one of two of such colleges that became a public university. (William \& Mary in Williamsburg, Virginia, is the other.) Another Rutgers claim to uniqueness is that it is the only colonial college to become a land-grant college, which it did in 1864, beating out the College of New Jersey (Princeton). The persuasive powers of Rutgers' first great scientist, George Cook, convinced the New Jersey legislature that Rutgers was a better choice for such a designation. When Rutgers became "The State University of New Jersey" through 
state legislation in 1945 and 1956, a hybrid governance structure developed with the Board of Governors representing the state university part of its identity and the Board of Trustees remaining in place in recognition of its origin as Queen's College.

Another interesting fact about Rutgers is that it does not have an unbroken history from its origins as Queen's College to Rutgers. Queen's College suspended operations, once during the Revolutionary War and again-after rejecting a possible merger with the College of New Jersey-from 1795 until 1807. After decades of financial struggle and seeking a variety of solutions, including fundraising efforts with lotteries, a different course was needed.

In his article "From Queen's College to Rutgers College," university archivist Thomas J. Frusciano charts the financial and factional problems within the Dutch Reformed Church leading up to the renaming of the college. Colonel Henry Rutgers (1745-1830) became the namesake of the institution in 1825 largely because of his friendship with Rev. Philip Milledoler and his well-known philanthropy regarding religious and educational endeavors. Milledoler (1775-1852) was president of Rutgers during the years 1825 to 1840 , beginning when Rutgers College emerged from Queen's College. He and Henry Rutgers were allies in the Dutch Reform Church faction that favored the New Brunswick location and the continued existence of the college, among other issues. Rutgers was known as a generous supporter of religious and classical education in Manhattan. He donated \$5,000 to the college and a bell that sits atop of the Old Queens building to this day. There was some understanding that the $\$ 5,000$ would be an annual donation, but that never happened and there was no mention of Rutgers College in his will.

Another curious fact is that for much of Rutgers' history, very little has been known about its namesake. Somehow Henry Rutgers has been lost in the shadows of time. Until recently, the longest biographical sketches on Rutgers were no more than few pages long. David J. Fowler, the author of a series of articles "Benevolent Patriot: The Life and Times of Henry Rutgers" in this 250th anniversary issue, remembers seeing in the mid-1980s a T-shirt bearing the question "Who the hell is Col. Henry Rutgers?" for sale on the New Brunswick campus. Little did he know then, he would become the person to answer the question.

With the support of the Rutgers Foundation, facilitated by John Pearson, the director of leadership gifts, and members of the 
Rutgers community, including Nicholas and Nancy Rutgers, Barry Kramer, and Bob Mortensen, Rutgers University Libraries opened an exhibition in 2010 devoted to Henry Rutgers: Benevolent Patriot: The Life and Times of Henry Rutgers. Fowler was the curator of that exhibition and his introductory essay on Rutgers in the catalog was the most substantial biographical sketch at the time. (A revised version of this is available at: https://libraries.rutgers.edu/rul/libs/ scua/university archives/henry rutgers.shtml; the entire catalog is available at http://dx.doi.org/doi:10.7282/T3KS6PQ8)

With continued support, Fowler was able to extend his research to an in-depth biography including Rutgers' ancestry and the times in which he lived. The results of this endeavor are being published in this journal, a series of engaging, well-written articles. In this, the first part of the special anniversary issue, we present Fowler's "Introduction" and "Part One: 1636-1776." In part two of the special issue to be published in the fall of 2016, Fowler continues the story to Rutgers' service in the Revolutionary War and after the war during the period when Rutgers rebuilt his fortune up to 1800 .

We conclude the first part of the special issue with my "Rutgers History in the Journal of the Rutgers University Libraries." Consisting primarily of an annotated bibliography of articles related to Rutgers history, this article demonstrates that the Journal is an important source for this institution's history. 